aro all negativo. Electrical conductivitios of molten salt mixtures containing lithium ions showed definite deviations from additivity.

A description was givon by Prof. M. Chemla (Paris) of measurements on diffusion and electrical mobility of cations in various halide or nitrato melts containing lithium, sodium, and potassium. The Nornst-Einstein relation was not obeyod, and relative mobilities of the ions changed with increasing tomporature. The rosults suggested formation of complexes or incipient clusters, the size of which decreasod and number incroased with increasing temperature. Queries wero raised about the validity of the method usod (counter-current electromigration) in detormining rolative ionic mobilities, and about the strict applicability of the Nernst-Einstein relation to molten salts.

The importance of measuroments of the tomporature dependence of the excess hoats of mixing was emphasized. Direct experimental values of excess functions would bo more helpful than indiroct measurements. Any statistical theory would give the excess free-onergy, $G E$, as a function of temperaturo, $T$, pressure, $P$, and composition, $x$.
Since critical points cannot be determined, the theory of corresponding states is not applicable to melts. Lattice theory applied at constant pressure tends to be uninformative, but constant volume measurements ought to be more useful. Experimental methods are now available for obtaining both first and second dorivatives of $G E$, but there is no satisfactory theory for $G E$ itself. This is unfortunate since it is very difficult to construct sensitive partition function theory for liquids based on socond derivatives.

It was roported that the heat of solution of water moleculos in lithium, sodium, potassium nitrato mixtures had been found to bo about $14 \mathrm{kcal}$. If the greater part of the solution energy is due to ion-dipolo interaction, the experimental rosults are in good agreement with theory. Finally, various speakers urged tho neod for an effort to correlato and assess the relative accuracy of various thermodynamic data available on molten salts. At the present time, thermodynamic data of increasing accuracy is gradually becoming available, but a satisfactory theoretical doscription of excess functions of molten salts is still lacking.
A. R. UBBELOHDE

\title{
PLANT WAXES AND CUTINS
}

A ONE-DAY moeting on "Plant Waxes, Cutins and Associated Compounds" was organized by the Phytochemical Group at the Sehool of Pharmacy, London, on January 7. The object of the meeting was to review the progress that has been made in this field since the 'thirties whon Prof. A. C. Chibnall and his colleagues separatod and idontified the odd- and even-numbered long-chain fatty acids in plant waxes. Tho chairman, Dr. G. S. Hartley (Chosterfield Park Research Station, Saffron Walden), in his opening remarks, roferrod to the very considerable comploxity of leaf surfacos and to the importance of knowing more about them, since much of present-day agriculture depended on the successful application of herbicides which would penetrate tho leaves of weeds, leaving crop plants undamaged.

A very elegant but simple method for obtaining close-up pictures of intact leaf surfaces has recently boen devoloped by Dr. B. E. Juniper (University of Oxford), who gave the opening paper. He showed electron-microscope photographs of the many difforent and complex crystalline patterns of the waxes that coat the leaf surfaces of most plants and described how loaf waxes provide a mechanism in pitcher plants for the retention of insects by preventing them from climbing out. In the second papor, Dr. G. E. Eglinton (University of Glasgow) reviewed the chemistry of leaf surface waxes, mentioning that besides the wellknown $n$-alkanes and their alcohol, aldehyde and acid derivativos, long-chain $\beta$-diketones, alkenes and branchedchain alkanos had recently boon found. Besides tho intrinsic interest of these substances as wax constituents, thero were indications, according to Dr. Eglinton, that alkane derivativos were of taxonomic value. Though there was much qualitative and quantitative variation in the chain-lengths of these hydrocarbons, their identification, by gas-phase chromatography, had become a routine matter.

Anothor technique that has been developed in recent years for separating leaf waxes is thin-layer chromatography, and in the third paper Dr. E. V. Truter (University of Loods), the pioneer in this field, described tho use of thin-layer chromatography for tho separation and analysis of the leaf waxes of the cabbage. Of the twenty-nine compounds present, the most important wore nonacosane and its rolatod primary alcohol, acid and estors. The related ketones, ketols and secondary alcohols, which woro also present, wore characterized by oxidativo fission and identification of the chain fragments by thin-layor chromatography on damp kieselguhr.

The plant cuticle, the non-cellular mombrane which covers the epidormis, appears to be chomically distinct from the wax above it. This is so, for example, in the apple fruit, which has been extensively investigatod by Dr. J. T. Martin of the Long Ashton Research Station, Bristol. While the wax contains the usual range of hydrocarbon derivatives and also the triterpenoid, ursolic acid, the cuticlo consists almost entiroly of esters of 10,16-dihydroxyhexadecanoic and 9,10,18-trihydroxyoctadecanoic acids. Dr. Martin also found tannins, quorcetin glycosides and other phenols in the cuticle, but commonted that they did not appear to participate directly in the cutin complex. The next paper, by Dr. P. Mazliak of the Sorbonne, Paris, dealt with the metabolism of apple fruit waxes. Radioactive acetate was supplied to growing applo peel and the waxes were lator saponified and analysed by gas chromatography. To his surprise, Dr. Mazliak found that, although the alcohols and acids such as linoleic and oleic acids wore labelled as expocted, there was no radioactivity in the paraffins. He obtained the same result with mature peel and could only concludo that the paraffins wore synthesized by a soparate pathway from the other wax constituents.

The final paper, by Dr. 1). F. Meigh (Ditton Laboratory, Maidstone), was concernod with the relationship betwoen apple waxos and storage disorders. He described his own investigations of superficial scald, the most important cause of wastage in the storod apple crop. Although the condition is controlled by wrapping apples in oiled tissue, its causo is as yet undetormined. Attempts to correlato the riso in concentration of linoleic acid in the apple skin at maturity with the incidence of scald have failed. Dr. Moigh did have some evidence that the paper wraps reduced the concentration of carboxyl compounds in the apple wax; another possibility was that volatile substances wore involved. It was clear from this and other papers that much more information is needed before practical problems involving leaf surfaces can be solved. As Dr. Hartley pointed out in his closing remarks to tho meeting, besides its main purpose as a skin to protect the plant from its immediate environment, the plant surface prosumably has to fulfil a range of other functions, about which we are still very ignorant.

\section{J. B. HaRborne}

